\title{
Myoid (Muscular) Hamartoma of the Breast: Case Report and Review of the Literature
}

\author{
Karol Kajo ${ }^{a}$ Pavol Zubor $^{\mathrm{b}}$ Jan Danko ${ }^{\mathrm{b}}$ \\ aDepartment of Pathology, \\ ${ }^{\mathrm{b}}$ Department of Obstetrics and Gynaecology, Jessenius Faculty of Medicine, Comenius University, Martin, Slovak Republic
}

Key Words

Breast · Hamartoma $\cdot$ Myoid $\cdot$ Muscular

\section{Summary}

Background: Myoid (muscular) hamartoma $(\mathrm{MH})$ of the breast is a rare benign tumour-forming lesion composed of differentiated mammary glandular and stromal structures, fatty tissue, and areas of smooth muscle. It is considered to be a variant of mammary hamartoma. Case Report: We report the case of a 46-year-old woman with $\mathrm{MH}$, and provide a literature review explaining the origin of smooth muscle cells. Histologically, the tumour consisted of fibrolipomatous stroma containing ductal and lobular structures of the mammary gland located mainly at the tumour borders. The glandular structures showed signs of micro- and macrocystic changes, apocrine metaplasia, and adenosis. The dominant feature was the presence of a fascicular formation of spindle cells, predominantly in central parts, with incursion between glandular structures. Immunohistochemically, foci of smooth muscle tissue were positive for desmin, smooth muscle actin, and h-caldesmon. Oestrogen and progesterone receptors (PR) showed positive expression which was markedly higher for PR. There was negative expression of CD34, S-100 protein, and CD10. Conclusions: The origin of smooth muscle cells in $\mathrm{MH}$ is unknown. However, it is presumed to be derived from hormonally responsive breast stromal cells by smooth muscle metaplasia, based on evidence of hormone receptor expression in the lesion.

\author{
Schlüsselwörter \\ Brust · Hamartom · Myoid · Muskulär
}

\section{Zusammenfassung}

Hintergrund: Das myoide (muskuläre) Hamartom (MH) der Brust ist eine seltene, gutartige, tumorigene Läsion bestehend aus differenzierten Strukturen des Drüsengewebes und des Stromas, Fettgewebe und glatter Muskulatur. Das $\mathrm{MH}$ wird als eine Nebenform des Hamartoms der Brust verstanden. Fallbericht: Wir berichten von einer 46-jährigen Frau mit $\mathrm{MH}$ und geben einen Überblick über die Literatur zur Herkunft der glatten Muskelzellen. Histologisch bestand der Tumor aus fibrolipomatösem Stroma sowie duktalen und lobulären Strukturen der Brust hauptsächlich im Grenzbereich des Tumors. Die Drüsenanteile zeigten Anzeichen von mikround makrozystischen Veränderungen, apokriner Metaplasie und Adenose. Das Hauptmerkmal war eine faszikuläre Formation von Spindelzellen, hauptsächlich im Zentrum des Tumors, mit Invasion interglandulärer Strukturen. Immunhistochemisch waren die Herde glatter Muskulatur positiv für Desmin, Smooth-Muscle-Aktin und h-Caldesmon. Expression der Östrogen- und Progesteronrezeptoren (PR) war positiv und deutlich höher für PR. Expression von CD34, S-100-Protein und CD10 war negativ. Schlussfolgerungen: Die Herkunft der glatten Muskelzellen beim $\mathrm{MH}$ ist unbekannt. Aufgrund des Hormonrezeptorexpressionsmusters wird jedoch angenommen, dass sie durch Metaplasie aus hormonsensiblen Stromazellen der Brust entstehen.

\section{KARGER}

Fax +497614520714

Information@Karger.de

www.karger.com (c) 2010 S. Karger GmbH, Freiburg 


\section{Introduction}

The diagnosis of 'hamartoma' is defined as a tumour-forming mass of disorganized but well-differentiated cells autochthonous to their place of origin. Mammary hamartomas are wellcircumscribed breast lesions composed of a mixture of mammary tissue structures including glandular ducts, lobules, stroma, and fatty tissue [1, 2], the distribution, quantity, and maturation of which may vary considerably. Myoid (muscular) hamartoma $(\mathrm{MH})$ is considered to be a rare variant of mammary hamartoma, in which extensive foci of spindle cells [3] are present along with the natural breast tissue cells and supporting tissues. Their smooth muscle character has been confirmed ultrastructurally [4] and immunohistochemically via expression of smooth muscle actin [2, 5-7]. In normally developed breasts, except where nipple smooth muscle cells are absent, the term 'hamartoma' is considered inappropriate by some authors [8]. The name 'choristoma' is also unsuitable since this involves the presence of microscopically normal tissue of another organ alien to that site as a result of embryonic rest cells. Furthermore, it is known that $\mathrm{MH}$ does not occur until adulthood. However, if the histogenesis of this heterogeneous component is definitively clarified, e.g. via the metaplasia of stromal cells, the term 'hamartoma' should be accepted. If clinically evident, $\mathrm{MH}$ presents as a well-circumscribed, firm and mobile nodular mass, barely differing from a breast fibroadenoma [9]. Here, we present another case of this rare entity with a literature review focusing on its origin.

\section{Case Report}

A 46-year-old woman presented with a 3-year history of a tumour mass in her left breast diagnosed on ultrasonography and mammography, having been referred by her private gynaecologist for a final evaluation. Initially, a fine needle aspiration biopsy was performed yielding signs of a benign fibroadenoma. As the tumour had shown progression of growth over the previous 3 months, the patient requested a lumpectomy which was performed without any complications with a 4-8-mm margin to the adjacent breast tissue. Macroscopically, the tumour measured $17 \times 15 \mathrm{~mm}$ with clearly defined margins to the adjacent breast tissue. The cut surface was a grey-white colour, with a mainly dense structure with small cavities on the periphery. Histologically, the tumour consisted of a mature fibrolipomatous stromal component containing irregularly distributed ductal and lobular structures of the mammary gland located mainly at the tumour borders. The glandular structures showed signs of micro- as well as macrocystic changes, apocrine metaplasia, and focal signs of adenosis. The dominant feature was the presence of a fascicular formation of spindle cells, predominantly in the central parts of the tumour, with incursion between some glandular structures (figs. 1 and 2). Immunohistochemically, these cells were positive for vimentin, desmin, smooth-muscle actin, and h-caldesmon (fig. 3). Oestrogen (ER) and progesterone receptors (PR) showed positive expression which was markedly stronger for PR (fig. 4). There was negative expression of CD34, S-100 protein, and CD10 (table 1). The histomorphological picture was 'concluded' by the presence of a focal finding of a pseudoangiomatous stromal hyperplasia.
Fig. 1. Myoid hamartoma of the breast. Arrows show fascicules of smooth muscle (HE staining, magnification $\times 20$ ) .

Fig. 2. Detail of the fascicules of smooth muscle (HE staining, magnification $\times 200$ ).

Fig. 3. Immunohistochemical identification of smooth muscle actin in tumour cells.

Fig. 4. Immunohistochemical expression of progesterone receptors in glandular and smooth muscle cells.
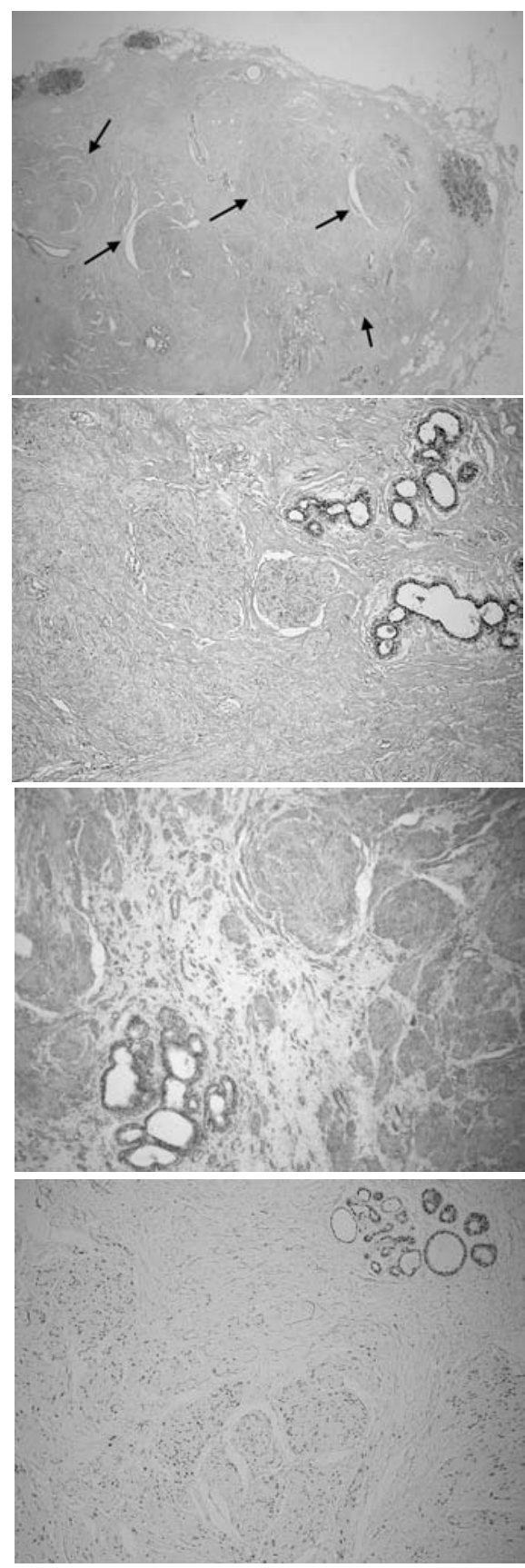

Table 1. Antibodies used in the diagnosis of myoid hamartoma

\begin{tabular}{llll}
\hline Antibody & Source & Clone & Dilution \\
\hline SMA & DAKO $^{\mathrm{a}}$ & $1 \mathrm{~A} 4$ & $1: 50$ \\
Desmin & DAKO $^{\mathrm{a}}$ & D33 & $1: 50$ \\
h-caldesmon & DAKO $^{\mathrm{a}}$ & h-CD & $1: 50$ \\
CD34 & DAKO $^{\mathrm{a}}$ & QBEND 10 & $1: 50$ \\
CD10 & Immunotech $^{\mathrm{b}}$ & CALLA & $1: 80$ \\
S100 polyclonal & DAKO $^{\mathrm{a}}$ & - & $1: 40$ \\
S100 monoclonal & Biogenex $^{\mathrm{c}}$ & 15E2E2 & $1: 100$ \\
Vimentin & DAKO $^{\mathrm{a}}$ & V9 & $1: 50$ \\
Keratin & DAKO $^{\mathrm{a}}$ & KL1 & $1: 200$ \\
Oestrogen receptor & Immunotech $^{\mathrm{b}}$ & ER1D5 & $1: 50$ \\
Progesterone receptor & Immunotech $^{\mathrm{b}}$ & 1A6 & $1: 50$ \\
\hline${ }^{\mathrm{a}}$ DAKO, Glostrup, Denmark. & & \\
${ }^{\mathrm{b}}$ Immunotech, Marseille, France. & & \\
${ }^{\mathrm{c}}$ Biogenex, San Ramon, CA, USA. & \\
\multicolumn{2}{l}{ SMA = Smooth muscle actin. } \\
\hline
\end{tabular}




\section{Discussion}

MH was described for the first time in 1973 by Davies and Riddell [10]. Its exact incidence is not yet known as there have not been more than 35 cases of $\mathrm{MH}$ described in the literature, mainly as case reports [2-7, 9-20]. The aetiopathogenesis of $\mathrm{MH}$ remains unclear, although there is a probable impact of female steroid hormones on cellular growth as all cases except one occurred in women [19]. Its prevalence is highest among postmenopausal women $[7,16]$ where it may persist for several years $[8,9]$. Various theories describing the origin of smooth muscle cells have attempted to explain the histogenesis of $\mathrm{MH}$ lesions $[2,8,15]$. In general, it is thought that the smooth muscle component in $\mathrm{MH}$ could originate from the smooth muscle cells of vessels, the nipple [11], undifferentiated breast tissue stroma [5], or myoepithelial cells [12]. Based on previous studies [12, 21, 22], Rosen [8] suggested that the majority of these lesions represent adenosis tumours with leiomyomatous metaplasia of the myoepithelial components. If the theory of transformation of myoepithelial cells into smooth muscle cells is correct, then at least some of the cells should express the protein S-100 or CD10 as markers of myoepithelial differentiation. Furthermore, in our case the foci of smooth muscle cells were localized mainly outside the glandular structures. Therefore, origin of the lesion from the smooth muscle cells of the nipple is unlikely in our case, as this lesion was localized well outside the nipple area. A more likely hypothesis is that the smooth muscle cells originated from breast stromal cell metaplasia. It is the presence of CD34 in smooth muscle cells that some authors consider a crucial sign of stromal cell metaplasia into smooth muscle cells $[2,5]$. Although we did not prove CD34 expression in the foci of smooth muscle cells, expression of this antigen was detected in the loci of the pseudoangiomatous stromal hyperplasia within the $\mathrm{MH}$, as described previously [23], thus confirming its hormonal origin [24]. Supplementary evidence supporting this hypothesis of metaplasia, hormonal aetiopathogenesis, and sensitivity, is the presence of hormonal receptors in smooth muscle cells. It is known that the adult breast contains only proliferative fibroblastic or myofibroblastic stroma expressed only as the ER $\beta$ type. The ER $\alpha$ form only has a role during the period of breast development in childhood and adolescence $[25,26]$. It has been shown that in fibroepithelial lesions such as fibroadenomas and phyllodes tumours there is a myofibroblastic proliferation of stroma mediated by oestrogen acting via $\operatorname{ER} \beta$, but not $\mathrm{ER} \alpha$, where the expression of smooth muscle markers correlates with the positivity for ER $\beta$ $[25,26]$. Therefore, it was very interesting to find $\mathrm{ER} \alpha$ and PR expression in smooth muscle cells in our case. This could be evidence of the origin of smooth muscle tissue in $\mathrm{MH}$ that could mimic the final step in smooth muscle differentiation with the intersection of myofibroblasts associated with a subsequent change in hormone receptor status $(\mathrm{ER} \beta$ to $\mathrm{ER} \alpha)$, or show that smooth muscle tissue could originate from vessel muscular bands, as these types of muscle cells express ER $\alpha$. Finally, a dual origin of $\mathrm{MH}$ has been considered where myoepithelial and myofibroblastic components are present in various proportions [2, 13]. A case was found containing mature cartilaginous tissue [4], which supports this hypothesis about the origin of metaplastic cell differentiation trends in mammary hamartomas.

Some MHs contain muscle cells with epithelioid features resembling the growth pattern of lobular invasive carcinomas, which makes diagnosis difficult, especially if small samples of bioptic tissue (e.g. from core biopsy) are evaluated [16]. Glandular components frequently show cystic and atrophic changes or signs from the spectrum of adenosis. Recently, a lobular neoplasia was found in an $\mathrm{MH}$ [27]. Microcalcifications may also be found in old lesions [9].

In the differential diagnosis, a fibroadenoma and other spindle cell lesions of the breast, e.g. fibromatosis, myofibroblastoma, benign tumours of peripheral nerve sheaths, and leiomyoma, should be considered. Fibroadenoma presents with a typical peri- or intracanalicular growth pattern in which normal mammary lobules are a rare finding. Fibromatosis is characterized by infiltrative growth and alternation of high cellular foci with hypocellular fibrotic areas. Immunohistochemically, the cells are frequently positive for $\beta$-catenin. Myofibroblastoma usually lacks entrapped glandular structures, and the cellular background is a mass of myofibroblasts growing in bundles interlaced with broad bands of hyalinized collagen. Benign tumours of peripheral nerve sheaths are characterized by the expression of S-100 protein, similar to myoepithelial tumours. A leiomyoma is classified as a tumour consisting only of smooth muscle, which lacks other components typical of $\mathrm{MH}[8]$.

Clinically, $\mathrm{MH}$ is practically indistinguishable from other benign breast lesions because of its clearly defined margins and firm-elastic consistency. Most of these tumours are asymptomatic and are diagnosed on mammography or breast sonography. However, women may palpate bigger ones themselves [7], and despite their infrequency it is presumed that the number of such cases will increase as a result of regular screening programs [9]. Although on sonography or mammography these lesions may show some characteristics related to tissue density (e.g. cystic changes, radiolucent halo), these examinations usually produce only a general diagnosis: a benign lesion in the range BIRADS 2-3 [6-8, 14, 16, 28], and the exact diagnosis is only obtained on histological examination. From the clinical aspect, the management of an $\mathrm{MH}$ benign breast lesion is similar to that of fibroadenoma, and there are no particular concerns regarding recurrence. Thus, extirpation does not require strict free margins or follow-up as in premalignant or cancerous lesions. However, as MHs are very rare breast lesions, it is of interest for clinical practice to carry out a detailed histopathological description and subsequent follow-up of these patients to achieve as much information as possible about the biological behaviour of these breast 
tumours. In the case of patient concerns about tumour growth progression, pain, or breast asymmetry, a core biopsy is at least necessary to obtain the diagnosis and exclude possible aggressive lesions. Moreover, complete surgical removal is a viable solution [2, 6]. In conclusion, the $\mathrm{MH}$ is a rare benign tumoriform lesion of the breast of unclear origin from a smooth muscle component, the clinical management of which is similar to other benign tumours of the breast.

\section{Acknowledgements}

We would like to thank Dr. Malcek from the Dept. of Pathology in Lucenec for his technical co-operation and Mali Ann Lajciak for correction of the manuscript. This study was supported in part by the grant VEGA 1/0069/09 from the Slovak Ministry of Education and by the project 'Centre of Excellence for Perinatology Research' co-financed by EC sources.

\section{Conflict of Interest}

The authors declare no conflict of interest.

\section{References}

1 Arrignoni MG, Dockerty MB, Judd WS: The identification and treatment of mammary hamartomas. Surg Gynecol Obstet 1971;133:577-552.

-2 Murugesan JR, Joglekar S, Valerio D, Bradley S, Clark D, Jibril JA: Myoid hamartoma of the breast: case report and review of the literature. Clin Breast Cancer 2006;7:345-346.

3 Chao TC: Myoid hamartoma of the breast. J Med Ultrasound 2005;13:206-209.

4 Huntrakoon M, Lin F: Muscular hamartoma of the breast. An electron microscopic study. Virchows Arch A Pathol Anat Histopathol 1984;403:307-312.

5 Magro G, Bisceglia M: Muscular hamartoma of the breast. Case report and review of the literature. Pathol Res Pract 1998;194:349-355.

6 Stafyla V, Kotsifopoulos N, Grigoriadis K, Bakoyiannis C N, Peros G, Sakorafas GH: Myoid hamartoma of the breast: a case report and review of the literature. Breast J 2007;13:85-87.

7 Takeuchi M, Kashiki Y, Shibuya C, Yamamoto S, Kitamura F, Nagao Y, Oota H, Yoshimi N: A case of muscular hamartoma of the breast. Breast Cancer 2001;8:243-245.

8 Rosen PP: Benign mesenchymal neoplasms; in Rosen's Breast Pathology, 3rd ed. Philadelphia, Lippincott Williams and Wilkins, 2009, pp. 833901.

9 Al-Sindi K: Myoid hamartoma: an exceptionally rare breast lesion. Bahrain Med Bull 2008;30:1-6.

10 Davies JD, Riddell RH: Muscular hamartomas of the breast. J Pathol 1973;11:209-211.

11 Bussolati G, Ghiringhello B, Papotti M: Subareolar muscular hamartoma of the breast. Appl Pathol 1984;2:92-95.
12 Daroca PJ Jr, Reed RJ, Love GL, Kraus SD: Myoid hamartoma of the breast. Hum Pathol 1985;16:212-219.

13 Di Tommaso L, Pasquinelli G, Damiani S: Smooth muscle differentiation in mammary stromo-epithelial lesions with evidence of a dual origin: stromal myofibroblasts and myoepithelial cells. Histopathology 2003;42:448-456.

14 Fiirgaard B, Kristensen S: Muscular hamartoma of the breast. A case report. Acta radiol 1992;33:115116.

15 Filho OG, Gordan AN, Mello Rde A, Neto CS, Heinke T: Myoid hamartoma of the breast: report of 3 cases and review of the literature. Int J Surg Pathol 2004;12:151-153.

16 Garfein CF, Aulicino MR, Leytin A, Drossman S, Hermann G, Bleiweiss IJ: Epiteloid cells in myoid hamartoma of the breast: a potential diagnostic pitfall for core biopsies. Arch Pathol Lab Med 1996;120:676-680.

17 Hayashi H, Ito T, Matsushita K, Kitamura H, Kanisawa M: Mammary hamartoma: immunohistochemical study of two adenolipomas and one variant with cartilage, smooth muscle and myoepithelial proliferation. Pathol Int 1996;46:60-65.

18 Khunamornpong S, Chaiwun B, Wongsiriamnuay S: Muscular hamartoma of the breast: a rare breast lesion containing smooth muscle. J Med Assoc Thai 1997;80:675-679.

19 Ravakhan K, Javadi N, Simms R: Hamartoma of the breast in a man: first case report. Breast $\mathrm{J}$ 2001;7:266-268.

20 Barbaros U, Deveci U, Erbil Y, Budak D: Breast hamartoma: a case report. Acta chir Belg 2005;105:658-659.
21 Eusebi V, Cunsolo A, Fedeli F, Severi B, Scarani P: Benign smooth muscle cell metaplasia in breast. Tumori 1980;66:643-653.

22 Shepstone BJ, Wells CA, Berry AR, Ferguson JD: Mammographic appearance and histopathological description of a muscular hamartoma of the breast. Br J Radiol 1985;58:459-461.

23 Rege JD, Shet TM, Pathak VM, Zurale DU: Mammary hamartomas - a report of 15 cases. Indian J Pathol Microbiol 1997;40:543-548.

24 Zubor P, Kajo K, Dussan CA, Szunyogh N, Danko $\mathrm{J}$ : Rapidly growing nodular pseudoangiomatous stromal hyperplasia in an 18-year-old girl. Case report. APMIS 2006;114:389-392.

25 Palmeri C, Saji S, Sakaguchi H, Cheng G, Sunters A, O'Hare MJ, Warner M, Gustafsson JA, Coombes RC, Lam EWF: The expression of oestrogen receptor (ER)- $\beta$ and its variants, but not $\mathrm{ER} \alpha$, in adult human mammary fibroblasts. J Mol Endocrin 2004;33:35-50.

26 Sapino A, Bosco M, Cassoni P, Castellano I, Arisio R, Cserni G, Dei Tos AP, Fortunati N, Catalano MG, Bussolati G: Estrogen receptor- $\beta$ is expressed in stromal cells of fibroadenoma and phyllodes tumors of the breast. Mod Pathol 2006;19:599-606.

27 Mathers ME, Shrimankar J: Lobular neoplasia within a myoid hamartoma of the breast. Breast J 2004;10:58-59.

28 Wong KW, Ho WC, Wong TT: MRI of muscular hamartoma of the breast. Australas Radiol 2002;46:441-443. 